Portland State University

PDXScholar

$9-1988$

\title{
From Myth to History: Yap Ah Loy and the Heroic Past of Chinese Malaysians
}

Sharon Carstens

Portland State University, b5sc@pdx.edu

Follow this and additional works at: https://pdxscholar.library.pdx.edu/anth_fac

Part of the Chinese Studies Commons

Let us know how access to this document benefits you.

\section{Citation Details}

Carstens, Sharon A. "From myth to history: Yap Ah Loy and the heroic past of Chinese Malaysians." Journal of Southeast Asian Studies 19.02 (1988): 185-208.

This Article is brought to you for free and open access. It has been accepted for inclusion in Anthropology Faculty Publications and Presentations by an authorized administrator of PDXScholar. Please contact us if we can make this document more accessible: pdxscholar@pdx.edu. 


\section{From Myth to History: Yap Ah Loy and the Heroic Past of Chinese Malaysians}

\section{SHARON A. CARSTENS}

The exploration of differing historical interpretations has become an area of growing interest to anthropologists and historians alike, who have come to recognize that diverse interpretations of the same events can create as powerful a force for future actions as the events themselves. Following this approach, history becomes not so much a narrative progression of events, as shifts in meaning structures over time. ${ }^{1}$ The impact of such a perspective on scholars of Southeast Asian societies has led to both an increasingly critical use of colonial sources as well as to renewed interest in native or indigenous documents. We have also come to expect major divisions not only between colonialist and indigenous views, but among indigenous views themselves. This is particularly true in societies divided by class and ethnicity such as Malaysia where competing political and cultural interests can be expected to produce markedly different versions of past events. Similarly, we can predict that ongoing shifts in political and cultural relations will create continued transformations in interpretations over time.

My purpose in this paper is to show how one set of rather unusual Chinese historical sources can illuminate the various and changing perceptions which Chinese in Malaysia and mainland China have had about the nature of political power, both at home and abroad. The documents concerned encompass fifty different biographical renditions of the life of the nineteenth-century Chinese Malayan leader, Yap Ah Loy. Written over a ninety-year period by different authors in Malaysia and China, these "historical accounts" convey a variety of understandings both about the Chinese position in Southeast Asia and about Chinese notions concerning the acquisition and maintenance of leadership and power.

The idea of history has, for thousands of years, played a very prominent and a very special role at every level of Chinese society: from the careful preparation of official histories by each succeeding dynasty, to popular theatrical presentations, to the historical metaphors found in religious rituals among Chinese peasants. Within this very diverse historical genre, the biographies of exemplary individuals have consistently

Research on Yap Ah Loy was funded by the following sources which are gratefully acknowledged: the Beloit College Cullister Fund (Summer 1982); a Fulbright Faculty Research Abroad Grant (1983-84); and a grant for use of the Hoover Collection at Stanford University (June 1985). This paper was presented in somewhat different forms at the Universiti Malaya, Beloit College, Northern Illinois University, Rutgers University and the University of Chicago. I am grateful for criticism and questions from these audiences and for particularly helpful comments on a later draft by Carl Trocki and Changtai Hung. All opinions and errors remain, of course, my own.

${ }^{1}$ Marcus and Fischer, Anthropology as Cultural Critique (Chicago: University of Chicago Press, 1986), p. 106. 


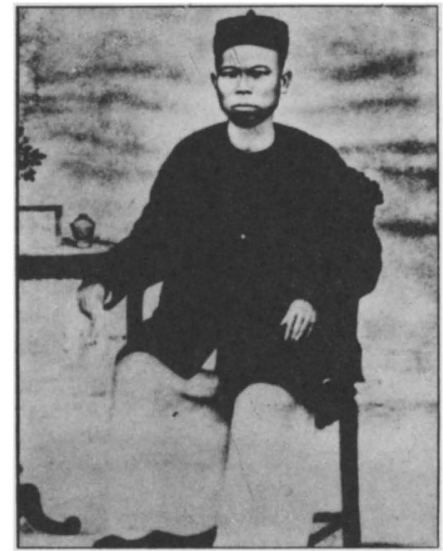

\section{Illustration 1}

The most common pictorial representation of Yap Ah Loy, found in the Yap Clan Association and the Si Shi Ye temple

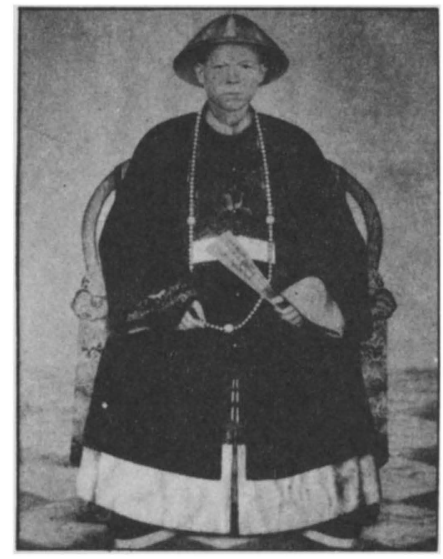

\section{Illustration 2}

Yap Ah Loy as a Chinese Mandarin (Courtesy of the Malaysian National Archives) 
served as vehicles for ongoing interpretations of ideology and morality. ${ }^{2}$ During the Ming Dynasty, for example, individual biographies accounted for 60 per cent of the official history as well as sizeable portions of the local histories or fangzhi. The categories used to classify individuals within these official texts, such as filial sons, loyal officials or virtuous widows, clearly defined their roles as moral exemplars. At the other "less official" end of the spectrum, stories of popular historical and pseudo-historical personages, such as characters from the Tale of the Three Kingdoms, accounted for a significant proportion of the dramatic plots in plays staged in villages, market towns, and cities. Similarly, the fortune slips found in local temples commonly compared the supplicant's fate with that of a famous historical individual. ${ }^{3}$ These "historical biographies", in whatever form they appeared, were clearly culturally ordered, and in a complicated social and political order such as the Chinese, one would expect that these cultural interpretations varied both in terms of social class and over time. ${ }^{4}$

As the disputed founder of the Malaysian capital of Kuala Lumpur, Yap Ah Loy's name and exploits are familiar to most modern-day Malaysian Chinese. Physical reminders of his former glory still remain in the heart of the oldest section of the city, where in close vicinity to the short street named Yap Ah Loy, the former Kapitan is worshipped as an illustrious ancestor on the central altar of the Yap Clan Association. Across the way, in the Si Shi Ye Temple, this same man is honoured on a side altar as a minor local deity (see illustrations 1 and 2). These visible markers, however, have not created as strong an impression on the public consciousness as the controversy in the Malaysian press since 1980 over Yap Ah Loy's status as founder of Malaysia's capital. The question at face value revolves around the definition of city founder: does one credit the first important person on the scene (that is, the Malay raja who sponsored the first large-scale tin mining in the area) or the person who expended the most effort in early years to build and develop the city (in this case, Yap Ah Loy, the third Chinese Kapitan of Kuala Lumpur)? Of course, the real point of this debate, as everyone knows, centres on which ethnic group will be credited with the founding of the nation's capital. For now, the issue has been decided in favour of the Malays. The school textbooks have been changed, and Raja Abdullah of Klang is now named by official sources as Kuala Lumpur's true founder.

\footnotetext{
${ }^{2}$ For a more detailed description and evaluation of the Chinese biographic tradition, see Richard Howard, "Modern Chinese Biographical Writing", Journal of Asian Studies 21 (1962): 465-75; David S. Nivison, "Aspects of Traditional Chinese Biography", Journal of Asian Studies 21 (1962): 457-63; Dennis Twitchett, "Chinese Biographical Writing", in Historians of China and Japan, ed. W.G. Beasley and E.G. Pulleyblank (London, 1961), pp. 95-114 and "Problems of Chinese Biography", in Confucian Personalities, ed. A.F. Wright and D. Twitchett (Stanford: Stanford University Press, 1962), pp. 24-39; and Wang Gungwu, "The Rebel-Reformer and Modern Chinese Biography", in Self and Biography: Essays on the Individual and Society in Asia, ed. Wang Gungwu (Australia: Sydney University Press, 1975), pp. 185-206. While Wang Gungwu and others have bemoaned the lack of individuality presented in official Chinese biographies, the stereotyped formats reveal cultural ideologies of great interest to the anthropologist.

${ }^{3}$ See, for example, Wolfram Eberhard's essays on the interrelationship between Chinese temples, theatre, and popular history in Studies in Chinese Folklore and Related Essays (Bloomington: Indiana University Research Center for the Language Sciences, 1970).

${ }^{4} \mathrm{See}$, for example, David Johnson's pioneering article, "Communication, Class, and Consciousness in Late Imperial China", in Popular Culture in Late Imperial China, ed. Johnson, Nathan, and Rawski (Berkeley: University of California Press, 1985), pp. 34-72.
} 
The 1980s debate between the Malays and Chinese over Kuala Lumpur's founder marks neither the beginnings of Yap Ah Loy's popularity among the Chinese, nor the first time he has served as the exemplar of a popular cause. Judging from a review of the literature on Chinese Malaysian leaders, Yap Ah Loy has, since the 1920s, been the most frequently written about Chinese Malaysian of his time, with at last count over fifty biographical accounts in scores of different publications (see Table I). His story reads, in many ways, like a generic myth ${ }^{5}$ of the overseas Chinese: that of a penniless, uneducated immigrant who became rich and famous in the Nanyang. Yet his fighting abilities, his ultimate success during the Selangor Wars, and his administrative and fiscal measures in governing early Kuala Lumpur set him apart from most other wealthy Chinese entrepreneurs of his time: men who concerned themselves almost exclusively with their own wealth and social standing. The growth of legends about Yap Ah Loy and the changes in these stories over time reveal shifts in Chinese attitudes about the acquisition and use of power and about their place in the Nanyang. They also demonstrate the manner in which a more mythic sense of history common to Chinese writers and intellectuals of the first half of this century became transformed into a positivistic secular recounting of assumed facts among Chinese Malaysians as they sought to fit themselves into a political and social world which was culturally pluralistic.

\section{TABLE I}

\section{PUBLISHED BIOGRAPHIES OF YAP AH LOY}

\section{Number Published: 1893-1979}

Chinese: 40

English: 8

\section{Chinese/Malay: 2}

II. Types of Publications
a. Chinese Association book
b. Book on famous Malayan/Nanyang Chinese
c. History or general book on Malaya/Nanyang Chinese
d. Newspaper account
8
e. Magazine or Journal
f. Children's/Young Peoples' book
g. Others
5
4

Chinese

English

\section{Chinese Accounts: Place and Date of Publication}

\begin{tabular}{lcccc} 
& $1905-1939$ & $1949-59$ & $1960-69$ & $1970-79$ \\
Malaysia/Singapore & 2 & 13 & 7 & 5 \\
Mainland China & 10 & 0 & 0 & 0 \\
Taiwan/Hong Kong & 0 & 4 & 1 & 0 \\
\hline
\end{tabular}

${ }^{5}$ For the purposes of this paper, I use the words myth and legend interchangeably to refer to culturally stereotyped stories of heroic deeds usually based on some sort of supernatural assistance. 
While both mythic and secular histories are cultural interpretations, they reveal themselves as interpretations of a different order. The conveyor of mythic history assumes a common cultural understanding of an abstract symbolic order; hence myths do not translate well from one culture to the next. Yet secular histories appear to be able to do just that, claiming to refer to the observable "facts" of events, with the truth statements now embedded in the events themselves. Chinese interested in cultural statements about power, its origins, manifestations, and usefulness, when writing for other Chinese who understood the abstract symbolic language of Chinese history, created versions of Yap Ah Loy's life which cast him in the mould of traditional Chinese heroes. In contrast, Chinese Malaysians, who sought to use Yap Ah Loy's accomplishments as a means of convincing other ethnic groups of the important historical position of the Chinese in Malaysia, became drawn instead to the language of secular history. To better understand and interpret these stories, let us begin with an abridged version of Yap Ah Loy's life, based on a combination of sources but drawing most closely on family documents. ${ }^{6}$

\section{Yap Ah Loy: The Standard Biography}

Yap Ah Loy was born in 1837 in the Hui Zhou Hakka district of Guangdong Province. The first son in a poor farming family, he received little or no formal education during his childhood, and at age seventeen travelled alone to Malaya, landing in Malacca in 1854. Here he was met by another man of the Yap surname who introduced him first to a job in a nearby tin mine, and when this operation closed down, to another "relative" who ran a shop in the mining town of Kesang. A year later this "uncle" decided to send the young man back to China, giving him money for his ticket home. But while waiting for his boat to sail in Singapore, Yap Ah Loy gambled his ticket away and was forced to remain in Malaya.

Avoiding his "uncle", he joined up with another relative and the two walked north to Lukut, a flourishing tin minting area in present day Negri Sembilan. Here he found work as a cook at a tin mine operated by another Hui Zhou Hakka named Chong Chong, and within three years had saved enough money to begin a pig trading business. Following his expanding trading activities, he travelled to nearby Sungei Ujong, where he made the acquaintance of a certain Liu Ngim Kong, who was serving as a personal bodyguard for the Chinese Kapitan of the area, Kapitan Shin. Both of these men were also Hui Zhou Hakkas, and Yap Ah Loy was taken on as another assistant bodyguard to Kapitan Shin. Not long afterward, fighting erupted between Malays and Chinese over the collection of tin revenues in the area; Yap Ah Loy joined in the battle on the losing side of Kapitan Shin and Liu Ngim Kong. Liu was wounded and escaped. Yap Ah Loy, also wounded, fled into the jungle where he hid with a family of charcoal makers. But Kapitan Shin was much less fortunate. Making a wrong turn on the jungle

\footnotetext{
${ }^{6} \mathrm{My}$ main source is S.M. Middlebrook's biography which was based largely on family documents. Begun in the 1930s and completed by J.M. Gullick after Middlebrook's death, it gradually came to be considered the standard biography by most writers. See S.M. Middlebrook, "Yap Ah Loy (1837-1885)", Journal of the Malayan Branch of the Royal Asiatic Society (JMBRAS) 24, no. 2 (1951): 1-127.

${ }^{7}$ Renditions of Chinese personal names in the following account are based on commonly used Chinese Malaysian romanizations which follow dialect pronunciations. All other Chinese terms and the names of Chinese authors cited in this article use Pinyin romanization. Please consult the glossary for character references.
} 
trail, he was caught and beheaded by a group of Malays. According to reports, however, a miracle took place at his death when white blood, instead of red, flowed from his body. Six months later, when the fighting had died down, Yap Ah Shak, the principal miner in Sungei Ujong, was offered the position of Kapitan. He turned it down, suggesting instead the appointment of Yap Ah Loy, who at the age of twentyfour became Sungei Ujong's new Kapitan.

A year later in 1862, at the invitation of his old friend Liu Ngim Kong, who was now acting Kapitan of the fledgling Kuala Lumpur area, Yap Ah Loy travelled north with three close friends and became Liu Ngim Kong's personal assistant. The move to Kuala Lumpur marked the beginning of a period of real prosperity for the young Yap Ah Loy. Within two years he owned two tin mines of his own and opened a drug store in town. Soon afterwards, he arranged to marry a Malacca Chinese woman and sponsored the construction of Kuala Lumpur's first Chinese temple dedicated to none other than the spirit of Kapitan Shin, who having died a miraculous death, was believed to now act as the powerful god, Si Sen Ta.

When Liu Ngim Kong fell ill in 1868, he made arrangements for Yap Ah Loy to fill the post of Kapitan after his death, much to the displeasure of certain relatives of Liu's, who were later to cause great trouble to Yap Ah Loy in the Selangor disturbances. As soon as Yap Ah Loy assumed the post of Kapitan, he began to make provisions for public order, publicizing a list of crimes and their punishments, recruiting a sizeable personal bodyguard, and training soldiers as a possible defensive measure. Disputes among Malay royalty over the collection of tin revenues from the growing tin fields had already flared up with the seizure of Port Klang by Raja Mahdi in 1866. When Yap Ah Loy took over as Kuala Lumpur's Kapitan in 1868, Raja Mahdi organized lavish ceremonies for his inauguration, partly as a move to legitimize his own position. In 1869 , Klang was again besieged and finally retaken by Tunku Kudin, the younger brother of the Kedah Sultan, a new son-in-law of the Selangor Sultan and an ally of Yap Ah Loy. ${ }^{8}$

In addition to the Malay dissensions over tax collection, the Chinese in the area around Kuala Lumpur were divided into competing camps which vied for control over the area's tin fields. In Kuala Lumpur itself, Yap Ah Loy was head of the mostly Hui Zhou Hakkas, while to the north in Kanching, the Jiaying Zhou Hakkas supported other leaders. Thus, the complicated battles of the Selangor wars, lasting from 1870-73, involved Chinese and Malays on both sides. The fighting see-sawed back and forth, then tipped against Yap Ah Loy, with the desertion of several Malay allies. Kuala Lumpur fell to the enemy in 1872, but was retaken by Yap Ah Loy with the help of Tunku Kudin and Malay soldiers from Pahang in 1873. The Selangor Sultan now installed Yap Ah Loy as Kapitan of Kuala Lumpur for the second time.

The city and mining region to which Yap Ah Loy returned had been devastated by three years of civil war, but he was determined to restore the mines and the city to their former prosperity. With his personal fortune largely depleted in the recent fighting, Yap Ah Loy was forced to borrow heavily from merchants in Malacca and Singapore. As a means of obtaining cheaper supplies for his workers, he encouraged local Malays to settle in the area and grow rice for him. Despite his many efforts, Kapitan Yap was

${ }^{8}$ On Kudin, see J.M. Gullick, "Tunku Kudin in Selangor 1868-1878”, JMBRAS 54, no. 2 (1986): $5-50$. 
on the verge of bankruptcy in 1878 when the price of tin suddenly doubled, enabling him to recoup his losses, pay his debts, and once again become one of Selangor's wealthiest men.

Meanwhile, the British had established themselves at Klang. When they moved their administration to Kuala Lumpur in 1879, Yap Ah Loy relinquished some of his powers as administrator but continued to represent the Chinese community as Kapitan in dealings with the British and Malays. ${ }^{9} \mathrm{He}$ also not only continued as a major tin magnate, but built roads, invested in various agricultural schemes, and was the first to import a steam pump for use in the Selangor mines. As a philanthropist he built a refuge which offered free food and shelter to the sick and he led in the building of Kuala Lumpur's first Chinese school. In 1885, just as he was planning to return to China for a long awaited visit, he fell sick and died, at the still youthful age of 48 , leaving behind a wife and two young sons.

\section{Malayan Accounts of Yap Ah Loy: 1885-1939}

It is not difficult to imagine how the accomplishments of Yap Ah Loy's life, his rise from the bottom of the social order to the top, and his numerous successes in battle, in business, and in governance might provide a popular and useful role model for Chinese Malaysians. And this, in the end, is what happened. Nevertheless, during the first fifty years following his death, written evidence indicates a much greater interest in his story among Chinese in mainland China than in Malaya itself. This difference in response to Yap Ah Loy's life was the product of varying social and intellectual milieus in the two places. In order to better appreciate these differences, we will examine these materials separately, beginning with the Malayan accounts, then moving to those produced by mainland Chinese, and finally returning to Malaysian writings following World War II.

There were no published Chinese accounts of Yap Ah Loy's life in the immediate period following his death. ${ }^{10} \mathrm{His}$ family, of course; held their own personal documents, including a short description of the Selangor wars, said to have been composed by Yap Ah Loy himself." Sometime after his death, his family commissioned one of his closest advisors, Hui Fatt, to compose a short account of Yap Ah Loy's activities in Malaya up to the end of the Selangor wars. This was edited by his children and grandchildren but remained during this period a private family document. ${ }^{12}$

The Hui Fatt record of Yap Ah Loy's activities in Malaya began with highly stylized comments to the effect that Yap Ah Loy "was fond of learning ever since he was a

\footnotetext{
${ }^{9}$ On the British and Yap Ah Loy, see Ernest Chew, "Frank Swettenham and Yap Ah Loy: The Increase of British Political Influence in Kuala Lumpur, 1871-1885", JMBRAS 57, no. 1 (1984): 70-87.

${ }^{10}$ The one possibility for a local Chinese obituary would have been in the Lat Pao, a Chinese newspaper which began publication in Singapore in 1881 . Unfortunately, there are no extant copies of this newspaper before 1887 , but judging from later editions, it seems highly unlikely that the Lat Pao would have printed an obituary of the Kuala Lumpur-based Kapitan.

${ }^{11}$ For a complete description of the Yap family documents, many of which can no longer be located, see Middlebrook, "Yap Ah Loy", pp. 120-24.

${ }^{12} \mathrm{~A}$ text of the document referred to (titled "Translation of Extracts from a Record made in Chinese by Yap Ah Loy relating to the War in Selangor before the year 1874") was first published in 1957 in English and Chinese in the Journal of the South Seas Society 13, no. 1:1-26. The compilation of such
} 
child" and "he embraced the thought of devoting his life to serve his country and people". Yap Ah Loy's activities during his early years in Malaya, including working for his two relatives, gambling his ticket away, his friendship with Liu Ngim Kong and Kapitan Shin, and his first position as Kapitan of Sungei Ujong were covered quickly. At least four-fifths of the ten thousand-word account described in great detail, and with considerable accuracy, the events of the Selangor disturbances, including the activities of the major Malay actors as well as the Chinese. Here is where the story ended, and there was no mention of Yap Ah Loy's struggles and successes in rebuilding Kuala Lumpur. Throughout the record, Yap Ah Loy's character appeared competent and determined, but it was the constantly shifting events, not the character of a great man, which carried the narrative along. Yap Ah Loy was portrayed as a man who, knowing his duty in his relations with others, did his best to follow it. Such an evaluation, while undeniably positive, was quite unlike the heroic character of Yap Ah Loy in later accounts, and it would seem that, among other things, time and distance were necessary for the development of the heroic legend which eventually took over.

The British obituary of Yap Ah Loy, appearing in the Straits Times two months after his death, was notable both for its pro-British slant and its inaccuracy about his earlier career. It claimed, among other things, that Yap Ah Loy had fought under Kapitan Pah Lok Chai (Kapitan Shin) during the Selangor battles between Tunku Udin (Kudin) and Raja Mahdi. The reporter also implied that the Kapitan's death had resulted in part from his refusal to seek European medical advice. Yap Ah Loy was described as an "enterprising man" who imported the first steam machinery into Selangor State, and served as a Magistrate and Member of Council (for the British).13

One wonders where the British reporter got this information; surely most of Kuala Lumpur's Chinese residents must have known of Yap Ah Loy's leadership during the Selangor disturbances? Yet orally transmitted stories seem to have a way of changing very quickly, not only due to difficulties of hearing and memory, but also to the exigencies of politics. We can surmise that any number of stories about Yap Ah Loy's exploits of both a positive and negative nature circulated freely among the Chinese in Kuala Lumpur before and after his death; a man of his wealth and power would have attracted his share of both admirers and detractors.

a biographical record by one's descendants, known as xingzhuang or "accounts of conduct", in addition to epitaphs and sacrificial odes, was not an unusual practice for wealthier families in China, where it formed part of the highly elaborated ancestral cult. See Nivison, "Aspects of Traditional Chinese Biography", p. 459. Such family records might have been used by historians writing biographical entries for official histories, particularly if the man had filled an important official position. See Twitchett, "Chinese Biographical Writing", pp. 103-107. Yap Ah Loy's family records never saw such use. Although he was the wealthiest and most powerful Chinese in Selangor during the later years of his life, holding the title of Kapitan of Selangor, this office was not recognized by the Qing government, and Yap Ah Loy received no mention in the Hui Zhuo Gazetteer of 1882 which was the last edition published. See Hui Zhuo Fuzhi (Taipei, 1970 reprint).

${ }^{13}$ Straits Times, 20 April 1885. 
The first indication of such Chinese stories appeared in 1893, eight years after Yap Ah Loy's death, in the locally published Selangor Journal. This biography was said to have been originally composed in Chinese in a seven character verse form by a Kuala Lumpur man. ${ }^{14}$ In spite of the translator's claim to having deleted certain unflattering passages, the overall impression left was decidedly negative. The first sentence of the piece reported that "Yap Ah Loy in his early days got into trouble", and this theme continued throughout the narrative.

In brief, the story reported that Yap Ah Loy fled poverty in China only to see his sufferings increase in a foreign land. He "ran away" from Klang to Malacca, then went to Sungei Ujong where Yap Ah Shak put him in charge of his gaming farm. After recovering from wounds suffered when Malays attacked Sungei Ujong, he worked first as a miner, then feeling dissatisfied, he "ran away" to Kuala Lumpur, where he established a money-making pig-trading business. Here he married a woman surnamed Koh and was named to succeed Liu as Kuala Lumpur's Kapitan. The Selangor disturbances, in which he subsequently became involved, were described as deriving from disagreements first with the Jiaying Zhou Hakkas and then with Chong Chong. Yap Ah Loy's success was credited to advice from the deity Su Yap (Kapitan Shin, now become Si Sen Ta) who came down in a dream. Finally, when the battles were won "Yap Ah Loy found the work too burdensome (so) he invited the English to look after the district and got a large pension and lived at ease for seventeen years." 15

The general message of this account was that Yap Ah Loy was a malcontent who constantly ran away from trouble, happened to be lucky in battle, but was too lazy to shoulder any real responsibility. To a certain extent, this could be read as a traditional Chinese caricature of a pre-destined but unwilling and possibly incapable leader; such character types did occur in Chinese fiction. ${ }^{16}$ Yet it also seems clear that the narrator, while well acquainted with many aspects of Yap Ah Loy's life, was no fan of the former Kapitan. Perhaps he belonged to a competing dialect group, like the Hokkiens, who had won the concession on the Selangor spirit farm just before Yap Ah Loy's death, or perhaps he was on bad terms with Yap Hon Chin, Yap Ah Loy's oldest son, who was known to literally "lord it over" others, including the British, who found him particularly insufferable. ${ }^{17}$ While we cannot ascertain exactly why this biography was so unflattering, it is safe to suppose that the negative portrayal was a product of personal or communal tensions among Yap Ah Loy, his heirs, and others residing in the Kuala Lumpur community. Composed by and for people who had known the former Kapitan, it served a very different purpose from later positive versions, separated from these concerns in both time and space. It is significant that this negative tone not only did not survive in later versions, but that by 1904, Yap Ah Loy had become transformed into a model hero on the Chinese mainland.

\footnotetext{
${ }^{14}$ It is unclear from this description whether the biography circulated was primarily in written or oral form or both. The verse format and the relatively short length (about twelve hundred words) suggest that it may have been included in the repertoire of local storytellers, but there is no way to substantiate this.

${ }^{15}$ C.K., "Yap Ah Loi”, The Selangor Journal 12, no. 1 (1893): 184-85.

${ }^{16}$ Robert Ruhlmann, "Traditional Heroes in Chinese Popular Fiction", in The Confucian Persuasion, ed. Arthur F. Wright (Stanford: Stanford University Press, 1960), pp. 155-61.

${ }^{17}$ Stories about Hon Chin are included in many accounts of Yap Ah Loy, where he is painted as a degenerate and profligate heir. Similar stories were related to me by Hon Chin's son, Yap Swee Hin, in conversations in Kuala Lumpur in 1982 and 1984.
} 
More than thirty years passed before the first laudatory biography of Yap Ah Loy appeared in the Chinese Malayan press, in a Chinese periodical published in Kuala Lumpur in $1927 .{ }^{18}$ Like the family record composed by Hui Fatt, this account also concentrated on descriptions of battle scenes from the Selangor disturbances, but it differed considerably in tone from the previous narrative in its effusive praise of Yap Ah Loy, who was portrayed as successful in all he attempted, whether in business, in city government, or in battle.

Of equal or greater interest was the inclusion for the first time of stories from Yap Ah Loy's childhood, absent from earlier family accounts and most likely apocryphal in origin. Such stories were a common feature of Chinese biographies, and reflected the Chinese belief that core elements of a person's character, revealed during youth, continued to manifest themselves through life. ${ }^{19}$ The imaginative quality of these stories suggested that the myth-making process had begun. The author noted that:

When he was born he was a common child and there was nothing remarkable about him.... He was not very big or tall and was of average size, but when he spoke his voice was sonorous. His temper was like fire and he had the strength of an elephant. He could support the weight of one hundred caddies on his two palms when he stretched his two arms forward.... He knew Chinese boxing. On his forehead between his eyebrows there was a mark like a Chinese character for man (ren) which he got when he was young tending cows in the village. The story goes that once he saw two bullocks fighting and he thought because of his exceptional strength he could separate them. Unfortunately one of the savage animals butted him on the head and so he got this deep mark like the Chinese character ren. ${ }^{20}$

Portions of this story reappeared in many later versions of Yap Ah Loy's life, some of them transformed to reveal new character traits. Such childhood stories not only conveyed particular messages about cultural values to their readers, ${ }^{21}$ they also implied that one was born to one's fate, and that leaders or heroes became successful as much through predestined processes as their own hard work.

\footnotetext{
${ }^{18}$ The translation of this article, entitled "The Biography of Yap Ah Loy", is located with the Middlebrook papers in the National Library of Singapore. No source is listed for the twenty-nine page manuscript except for a handwritten notation saying it came from a Kuala Lumpur periodical around 1927. There is no record of any Chinese periodicals published in Kuala Lumpur during this period other than the two Chinese newspapers Yit Khuan Po and Nanyang Siang Pau. No extant copies remain of the first for this time, and I was unable to find this article in the second.

${ }^{19}$ Twitchett, "Problems of Chinese Biography", p. 28.

${ }^{20}$ Anon., "The Biography of Yap Ah Loy" (1927), p. 1.

${ }^{21}$ For example, two biographies of Yap Ah Loy published in Taiwan during the late 1950s attempted to claim the virtues of filial piety for their hero by noting that the young Yap Ah Loy, on learning of his mother's illness while in Malaya, returned to China to nurse her, staying on until her death and arranging a proper funeral before returning to his life in Malaya. Making heroes conform to the stricter tenets of filial piety may have fit well with the political ideology of Taiwan in the 1950s, but it is not surprising that no such stories ever appeared in Malayan Chinese versions, for to demand such traits in their heroes contradicted the realities of overseas immigration, which often meant leaving the family home for good. Sun Yujing, Ye Delai (Taipei: Haiwai wenku chubanshe, 1956); Anon., "Ye Delai", in Malaia huaqiao zhi (Taipei: Huaqiao zhi piancuan weiyuanhui pianyin, 1959), pp. 288-91.
} 
The 1927 account of Yap Ah Loy's life by an unknown author was just about the last biography of him to be published in Malaya before World War II..$^{22}$ Meanwhile, on the Chinese mainland, numerous versions of his life appeared in the 1920s and 30s in popular and scholarly books and periodicals. This dearth of materials in Malaya and their relative abundance in China is at least partially explained by the varying social and intellectual milieus of the two places.

Although oral accounts of Yap Ah Loy's life very likely continued to circulate in Malaya for some time after his death, the publication of written accounts was limited by a number of local factors. To begin with, the overseas communities by and large lacked both a high percentage of literate residents and a scholarly class interested in literary production. ${ }^{23}$ Newspapers, the most common locally produced publications, were written and edited mainly by recent immigrants or political refugees from the Chinese mainland. Their concerns and perspectives, from the late nineteen hundreds up to the Japanese occupation, focused more on the economic, political and social problems of China than on local issues. ${ }^{24}$ Other types of Chinese publications such as books or journals, where available, were almost entirely imported from the Chinese mainland.

Even so, the Chinese Malayan mercantile elite did become inspired from time to time to produce public records of their accomplishments. One such publication, appearing in Penang in the 1920s, contained biographical accounts of over five hundred Southeast Asian (mostly Malayan) Chinese. According to informants, this project was organized by Penang newsmen who sold places in these books to Chinese who wished to have their own or their ancestors' biographies included, and the information for each entry was supplied by the purchasers themselves. The preface to the first edition contained revealing statements about the value system of Chinese Malayans at the time. Observing that it was time that history recorded more than just the actions of rulers and officials, the editor proposed new criteria for social status which recognized those Southeast Asian Chinese who used their wealth and skills to help China, whether through business or humanitarian relief. ${ }^{25}$ Once again, the focus was on China, and the

\footnotetext{
${ }^{22} \mathrm{~A}$ short account of about five hundred characters was published in a high school Malayan geography textbook in 1939. The story-line followed none of the versions so far described, but was related to a new heroic tale which first appeared in Shanghai in the 1920s. Zhang Liqian, "Ye Lai", Malaia dili keben (Singapore: Zhonghua chubanshe, 1939), pp. 33-34.

${ }^{23}$ The absence of a scholarly elite is a common observation made about overseas Chinese communities. See, for example, Wang Gungwu, "Traditional Leadership in a New Nation: The Chinese in Malaya and Singapore", in Community and Nation: Essays on Southeast Asia and the Chinese (Singapore: Heinemann Educational Books, Ltd., 1981), pp. 159-72. Given that the great majority of Chinese immigrants came from poor and uneducated backgrounds in China, the overall literacy rate in the late 19th and early 20th centuries must have been lower than the 30-45 per cent estimated by Rawski for the Chinese mainland. Evelyn Rawski, Education and Popular Literature in Ch'ing China (Ann Arbor: University of Michigan Press, 1979), p. 23.

${ }^{24}$ See Chen Mong Hock, The Early Chinese Newspapers of Singapore 1881-1912 (Singapore: University of Malaya Press, 1967); Wang Zibai, "Malaixia huawen baoye xiaoshi [A brief account of Malaysia's Chinese newspapers]", Nanyang wenzhai 6, no. 7 (1965): 31-35; John A. Lent, "Malaysian Chinese and their Mass Media: History and Survey", Asian Profile 2, no. 4 (1974): 397-412.

${ }^{25}$ Cheng Yunke, "Pianji nanyang mingren jichuan luchi" [Editorial preface to collected chronicles of famous men of the Nanyang], in Nanyang mingren jichuan, Vol. 1, ed. Lin Bo Ai, et al. (Penang, 1922), pp. $1-2$.
} 
key to success was in business and industry. ${ }^{26}$ Under these circumstances, it is quite understandable that Yap Ah Loy, who in previous writings had been depicted primarily as a fighter and defender of Malayan territory, received no mention. ${ }^{27}$ These very qualities, however, did earn the attention of Chinese writers elsewhere, who proceeded to shape Yap Ah Loy's story into the mould of a traditional Chinese hero.

\section{Mainland Chinese Accounts of Yap Ah Loy: 1905-1939}

In the early part of the twentieth century, news of Yap Ah Loy's exploits in the Nanyang began to appear in publications on the Chinese mainland. In 1905 his name was included as one of nine famous overseas Chinese colonizers in an article by Liang Qichao in Xinmin zongbao. During the 1920s and 30s, at least ten additional biographies of Yap Ah Loy were published in journals, travelogues, and books about the overseas Chinese. The accounts of Yap Ah Loy contained in these mainland publications varied greatly in content and style from the versions discussed so far, as they reflected very different conceptions of and concerns for the Nanyang than those held by the overseas Chinese themselves.

Official Chinese interest in Southeast Asia had waxed and waned over the centuries. During the late Qing period, the restrictive edicts forbidding Chinese travel, trade, and residence abroad were gradually lifted, 28 and the government set out to court overseas Chinese investment and financial contributions to their homeland. By the turn of the century, competing Chinese political groups vied for financial support for their causes in the Nanyang communities. ${ }^{29}$ The establishment of Jinan University in Shanghai as a school for the children of Chinese residing abroad was one means by which the government sought to further cement ties with its overseas compatriots, and it was at Jinan that the first scholarly journals dedicated to research on the Nanyang appeared in the late 1920s.

Meanwhile, articles about Southeast Asia and its Chinese communities also began to appear in other popular and scholarly journals. ${ }^{30}$ Judging from the overall contents

\footnotetext{
${ }^{26}$ Wang Gungwu similarly places merchants at the top of the overseas Chinese social hierarchy for this period, while Yong Ching Fatt has observed that in Singapore from 1900-1941, Chinese leaders were either English-educated professionals and businessmen or Chinese-educated merchants. Wang Gungwu, "Traditional Leadership in a New Nation: The Chinese in Malaya and Singapore", p. 162; Yong Ching Fatt, “A Preliminary Study of Chinese Leadership in Singapore, 1900-1941", Journal of Southeast Asian History 9 (1968): 258-85.

${ }^{27}$ Although Chinese informants told me that Yap Ah Loy's absence may have been due to lack of interest among his own descendants, I was also told that other famous Chinese had their entries inserted gratis in order to increase the prestige of the publication. Why these men should appear and not Yap Ah Loy is most likely related to the stated social values of the editors.

${ }^{28}$ Michael Godley, The Mandarin Capitalists from Nanyang (Cambridge: Cambridge University Press, 1981), pp. 61-63.

${ }^{29}$ Godley, Mandarin Capitalists; Yen Ching-hwang, The Overseas Chinese and the 1911 Revolution (Kuala Lumpur: Oxford University Press, 1976).

${ }^{30}$ The most useful bibliography of modern Chinese writing about Southeast Asia is that compiled by Nanyang University published in Singapore in 1968 entitled Nanyang yanjiu zhongwen qikan ziliao suoyin 1905-1966 [Index to Chinese Periodical Literature on Southeast Asia 1905-1966]. For further discussion of this source and other Chinese publications on Southeast Asia during this period see Sharon Carstens, "Chinese Publications and the Transformation of Chinese Culture in Singapore and Malaysia", in Changing Identities of the Southeast Asian Chinese since World War II, ed. Wang Gungwu and Jennifer Cushman (Hong Kong: Hong Kong University Press, forthcoming 1988).
} 
of these publications, interest in Southeast Asia was part of a much larger interest in foreign places in general, for many more articles were written about Europe, the United States, and Japan than Southeast Asia. But even while the western world attracted more extensive and more sustained attention, the overseas Chinese, as we shall see, in addition to being somewhat exotic, served well as object lessons for certain wider Chinese concerns.

The appearance of so many Yap Ah Loy biographies must also be understood within the context of a more general growth of biographic literature in China during this period. Intellectuals, decrying the bankruptcy of traditional Confucian culture, searched for "new models of individual behaviour" in both Western and Chinese literature. ${ }^{31}$ Among the types which most interested them were founder figures like Bismark, Darwin, and Gandhi, ${ }^{32}$ a category which could also apply to Yap Ah Loy.

The mainland Chinese biographies of Yap Ah Loy appeared in a variety of publications, and it would seem they were written for a number of reasons. On four different occasions ${ }^{33}$ Yap Ah Loy was included in a set of biographies about Chinese pioneers or adventurers in Southeast Asia; in three cases he was the most recent figure listed and the only Malayan Chinese. Four travellers to Malaya in the 1920s included accounts of his life as part of their descriptions of Kuala Lumpur; again Yap Ah Loy tended to be the only, or one of a very few Chinese so honoured in the entire book. ${ }^{34}$ Finally, separate articles about him, written by the Hakka scholar Lo Xianglin, appeared in two journals in the 1930 s. ${ }^{35}$

Given the time span of these various publications and the different contacts their authors had with oral or written sources, one would expect a certain amount of variation in the stories told, and this did indeed hold true for particular details about Yap Ah Loy's origins in China, geographic movements in Malaya, and the extent of his success. What was even more striking, however, was the great similarity in story line found in almost all of these versions.

\footnotetext{
${ }^{31}$ Howard, "Modern Chinese Biographical Writing", p. 465.

${ }^{32}$ Ibid., p. 467.

${ }^{33}$ Liang Qichao, "Zhongguo zhimin ba daweiren chuan" [Chronicles of eight famous Chinese colonizers], Xinmin zongbao 3, no. 15 (1905): 81-88; Wen Zongfei, "Ye Lai chuan" [The chronicle of Ye Lai], in Nanyang huaqiao tongshi (Shanghai, 1929), pp. 249-53; Gu Chuanchao, "Ye A Lai: Kaishi nanyang zhi shiwu weiren shilu" [Ye A Lai: Stories of fifteen great men who opened up the nanyang], Nanyang qing bao 1, no. 1 (1932): 19-20; Huang Yingchu, "Ye Lai" in Huaqiao mingren gushi lu (Changsha: Shangwu yinshu guanfahang, 1939), pp. 32-34.

${ }^{34}$ Huang Jiang, "Ji Ye Delai" [Remembering Ye Delai], in Malai hongxue lu (Shanghai: Shangwu yinshuguan, 1928), pp. 94-96; Jiang Kangchu, "Ye A Lai Shi" [The Undertakings of Ye A Lai] in Nanyou huixiang ji (Shanghai: Zhonghua shuju, 1928), pp. 24-25; Li Zhangchuan, "Sihui zhi huodong ji Ye A Lai shi" [The activities of secret societies and the affairs of Ye A Lai] in Nanyang huaqiao shi (Shanghai: Guoli jinan daxue nanyang wenhua shiyebu, 1929), pp. 51-54; Liang Zhaowen, "Jilengpo yu Ye Lai" [Kuala Lumpur and Ye Lai] in Nanyang luxing manji (Shanghai: Zhonghua shuju, 1924), pp. 121-23.

${ }^{35}$ Lo Xianglin, "Malaibandao jilengpo kaibi zhe Ye Lai chuan" [The chronicle of Ye Lai, developer of the Malayan Peninsula's Kuala Lumpur], Nanyang yanjiu 5, no. 4 (1935): 105-106; Lo Xianglin, "Ye Lai chuan", Zhongguo xinlun 2, no. 3 (1936). I have been unable to locate the editions of these journals; however, Lo Xianglin continued to write biographies of Yap Ah Loy in the 1950s and 60s which adhere to one basic story-line, and it is not unlikely that the 1930s articles followed the same plot. See Lo Xianglin, "Ye Lai" in Huaqiao mingren chuan, ed. Ju Xiuxia (Singapore: Nanyang daxue tushuguan, 1955), pp. 37-50; Lo Xianglin, "Jilengpo kaibi zhe Ye Lai chuan" [The chronicle of Kuala Lumpur's developer Ye Lai], Xin xiwang 63 (1955): 4-5; Lo Xianglin, "Jilengpo kaibi zhe Ye Lai chuan" in Yi tang wen zun (Hong Kong: Zhongguo xueshe, 1965), pp. 20-36.
} 
Basically Yap Ah Loy was portrayed as a fighting leader who won land for himself and his followers, usually wresting it away from the Malays, but ultimately having to give in to the British. The plots suggested a rather unified Chinese conception of overseas Chinese power relations where Malay, Chinese and British interests were seen as competing and distinct. These stories clearly glorified the idea of a fighting hero over that of successful merchant or even competent administrator, and Yap Ah Loy's singular inclusion in so many accounts further reinforced this impression.

Liang Qichao, the famous writer, intellectual, and reformist philosopher of late 19th and early 20th century China was the most explicit in his justification for writing about Yap Ah Loy and other Nanyang "colonizers". ${ }^{36}$ His biography of Yap Ah Loy, published in 1905 in his famous journal Xinmin Zongbao, was written during a period of residence in Japan. ${ }^{37}$ While the story he presented was short (about 450 characters) and clearly inaccurate, the message conveyed was obvious.

Yap Ah Loy was identified as a Guangdong man from Jiaying Zhou. Liang noted that during this time, the British occupied Singapore and the Johore harbour, where they collected land rents and prevented deep penetration into the peninsula by others. The Chinese, meanwhile, were involved in the tin mining business in Singapore and Penang, and as their numbers grew, they engaged in fights with the locals, which prompted the King of Johore to issue an order expelling all Chinese from the area. At this time, Yap Ah Loy's kinsmen in Johore numbered some three hundred people, and they discussed organizing resistance to the local king and elected Yap Ah Loy as their generalissimo. Although they were victorious in their early battles, they feared the king's revenge, and turned to China for some ten thousand kinsmen to join them in the fighting, which lasted for eight years and included all of Johore as well as Penang. Leading his army, Yap Ah Loy finally stabilized the whole area and obtained the land of the "barbarian" kings. However, because the English were also interested in controlling this area, an economic and political struggle began. As the British were backed by a strong government, but the overseas Chinese of that period were still considered pirates by the Qing authorities, Yap Ah Loy had no alternative but to turn over sovereignty of the whole territory to the British, and was barely able to retain control of his own private land..$^{38}$

Liang Qichao was clearly more interested in why the British became successful colonizers while the Chinese failed than in the man called Yap Ah Loy; this concern was evident in both the other biographies included in this collection as well as in comments which followed the biographies. Each of the "heroes" written about were Chinese who established significant kingdoms or communities overseas, only to have their names and glorious deeds forgotten in the mists of time. Liang Qichao bemoaned the Chinese neglect of these illustrious ancestors in his Afterword, contrasting their treatment with

\footnotetext{
${ }^{36}$ For further comments on Liang Qichao's article in reference to Chinese history writing about Southeast Asian Chinese, see Wang Gungwu, "Southeast Asian Hua-Ch'iao in Chinese History Writing", Journal of Southeast Asian Studies 11, no. 1 (1980): 1-14.

${ }^{37}$ It is unclear where Liang Qichao obtained his information; possibly he obtained some notes during his brief visit to Singapore in 1900 . The notation at the end of the piece indicated oral sources, and he lamented in an afterword his inability to obtain further information from villagers (xiang-ren) whom he said must have known the story. Whether he meant villagers in China or Malaya is not clear.

${ }^{38}$ Liang Qichao, "Yingshi haixia zhimindi kaibi zhe Ye Lai" [Ye Lai: Developer of the British Straits Settlements], Xinmin zongbao 3, no. 15 (1905): 85.
} 
characters from Western history such as Moses or Columbus who continued to be revered; and he warned about the dangers to China if Chinese citizens lost their spirit of hero worship. ${ }^{39}$

Although the 'message' of Liang Qichao's story clearly reflected current political concerns, the form in which this message was expressed adhered closely to the standard stereotypical tale of a "founder figure" from Chinese popular fiction. Such a figure, according to Ruhlmann

\begin{abstract}
...starts out as a strong man charged with the protection of a local community in a period of anarchy and disorder; his tiny band of followers snowballs into an army, and he eventually takes over provinces and perhaps the whole country, in part by battles and negotiations, but also in part by a mysterious charisma which wins him the spontaneous support of all who meet him. ${ }^{40}$
\end{abstract}

The charismatic part of this formula was not an important element in Liang Qichao's story, but it was soon to become an important character trait in subsequent versions circulating in both China and Malaya.

Although most of the other accounts of Yap Ah Loy's life published in China during the 1920s and 30s adhered to similar ideas about power relations between the Chinese, the Malays and the British, two different versions of Yap Ah Loy's biography appeared in 1928 and 1929 with a noticeably different slant on these matters. Huang Jiang's biography, published in 1928, had many of the earmarks of oral traditions collected locally, with a number of Malay elements included in the tale. ${ }^{41}$ Chief among these was the granting of land to Yap Ah Loy according to a Malay tradition which recognized suzerainty over an area demarcated by the sound of a gong beaten from the city centre. However, the moral of this story was still clearly Chinese, as it concluded with tales of Yap Ah Loy's profligate son, who served as a warning about the frequently degenerate descendants of wealthy and enterprising men.

An even more divergent and interesting biography appeared in Shanghai in 1929 with the publication by Wen Xiongfei of the book Nanyang huaqiao tongshi (History of the Nanyang Overseas Chinese). As a general history of Chinese immigration to and settlement in the Nanyang, the book included biographies in the third and final section in order to illustrate the more general themes and trends discussed earlier. The biography of Yap Ah Loy included here was both the longest and the most developed story of his life to appear in China during this period. Written in a semi-classical style, it wove a series of tales which served as the basis for many subsequent stories about the man and his life. Like the Huang Jiang biography, it displayed a great sensitivity to Malay political concerns, providing unusually accurate accounts of relations among the Selangor Malay royalty and acknowledging in its stories the legitimacy of Malay rule. ${ }^{42}$

At the same time, the narrative of Yap Ah Loy's rise to power followed more closely than ever the heroic traditions of Chinese popular literature. Beginning with childhood

\footnotetext{
${ }^{39}$ Liang Qichao, "Zhongguo zhimin ba daweiren chuan", pp. 86-87. For a more detailed discussion of Liang Qichao's interest in and use of the biographic form see Richard Howard, "Modern Chinese Biographical Writing", pp. 469-72; Joseph Levenson, Liang Ch'i-Ch'ao and the Mind of Modern China (Cambridge: Harvard University Press, 1966), pp. 105-109.

${ }^{40}$ Ruhlmann, "Traditional Heroes in Chinese Popular Fiction", p. 157.

${ }^{41}$ Huang Jiang, "Ji Ye Delai" [Remembering Ye Delai], Malai hongxue lu (Shanghai: Shanghai yinshuguan, 1928), pp. 94-96.

${ }^{42}$ Wen Xiongfei, "Ye Lai chuan", pp. 249-53.
} 
stories, the young Yap Ah Loy was depicted as an intelligent and courageous child who "became experienced in managing affairs in a chivalrous manner (yi xiayi ganlien) so that the village youth respected him as their leader". ${ }^{43}$ However, due to the depredations of the Taipings he realized as a young man that the only way to get ahead in his home area would be to become a bandit himself, and he decided instead to travel overseas to seek his fortune.

The next section of the story ascribed Yap Ah Loy's rise to power to a classic formula for Chinese heroes: a predestined leader with charismatic powers attracting both the support of the lower classes and the respect of the ruling elite. The author noted that:

When Yap Ah Loy arrived in Malacca, he was hired as a labourer, but once again found himself with barely enough to live on, so that he felt depressed and dissatisfied with himself. A fortune teller who lived with him, by the name of Guo Lung, observed that Yap Ah Loy's face revealed a noble spirit, predicting that he would not long be a subordinate of others. Seeing Yap Ah Loy's depression, Guo would comfort him with tales of men who rose as grass-roots heroes, and he questioned the possibility of success in scholastic and ethical pursuits for those who were poor. Guo prophesied that one day times would change, and then the way to display one's abilities would be through straightforward and frank talk.

Greatly moved by his words, Yap Ah Loy lost interest in working as a labourer. With his heroic spirit, chivalrous and generous nature, he gradually began mixing with the lower class elements in the market place (tugu shijing zhi tu) and before long was considered a leader of the workers (gongren kuishou). Just at this time news came that the Kuala Lumpur mines were recruiting workers with promises of great benefits. Yap Ah Loy thus travelled to Kuala Lumpur where he gradually became respected as the leader of the mining workers in that area. ${ }^{44}$

The story continued by describing how the Selangor Viceroy Kudin turned to the now established leader Yap Ah Loy for assistance in his battles with other Malay chiefs over control of the mining areas between Klang and Kuala Lumpur. With the help of newly arrived countrymen from China and their knowledge of fire rockets, Yap Ah Loy's army eventually triumphed, and his name became famous. The rest of the account dealt in considerable detail with the economic, political, and ceremonial rewards which followed, and included again the story of demarcating Yap Ah Loy's territory by the sounding of a gong.

Wen Xiongfei's biography of Yap Ah Loy was clearly cast in the Chinese heroic tradition of the knight-errant (xia), who had been a popularly recurring figure in Chinese literature for centuries. In general the term "applied to the kind of men who roamed around the country and used force to right wrongs". ${ }^{45}$ Although this was not really Yap Ah Loy's "mission in life", his behaviour from the time of his youth through his travels as an adult was described repeatedly as chivalrous (xiayi), and his leadership of the working masses represented one kind of defence of the weak against the strong. Such sympathetic depictions of lower class aspirations were a fairly common theme among mainland Chinese writers of the 1920s and 30 s. ${ }^{46}$ Even more to the point was the

\footnotetext{
${ }^{43}$ Wen, "Ye Lai chuan", p. 249.

${ }^{44}$ Ibid., pp. 250-51.

${ }^{45}$ James J.Y. Liu, The Chinese Knight-Errant (Chicago: University of Chicago Press, 1967), p. xii.

${ }^{46}$ Perry Link, Mandarin Ducks and Butterflies: Popular Fiction in Early Twentieth-Century Chinese Cities (Berkeley: University of California Press, 1981).
} 
great popularity of knight-errant fiction during the late $1920 \mathrm{~s}$, at the same time that news reports of the KMT army's Northern Expedition against warlordism "had a strong hold on the public imagination in the cities". ${ }^{47}$

The Yap Ah Loy thus described by Wen Xiongfei was clearly a romantic figure who belonged to "the masses". The message of his rise to power and his success carried somewhat different implications from the nationalist aspirations revealed in the stories of Liang Qichao and others. And these themes likewise contrasted with the concerns of Malayan Chinese writers of the time.

This, however, was soon to change. The Wen Xiongfei version of Yap Ah Loy's life was printed in condensed form in a Malayan geography textbook published in Singapore in 1939 for Chinese high school students. ${ }^{48}$ It was also repeated fairly closely in memorial volumes published by the Malaya Hui Zhou Association in Singapore in 1949 and by the Perak Hakka Association in 1951.49 And the identical story-line appeared as well in the Nanyang nianjian (Nanyang Yearbook) published in Singapore in 1951. ${ }^{50}$ It would seem that the heroic dimensions of this tale and its sensitivity to Malay political interests made such a story-line far more palatable to Malayan Chinese than other mainland versions such as Liang Qichao's and others. Nevertheless, this particular version of events was soon replaced with more detailed and more accurate accounts of Yap Ah Loy's service both during and after the Selangor wars, even while the emphasis on his chivalrous or heroic personality continued as a frequent theme in later accounts of the 1950s.

\section{Post World War II Accounts in Malaya and Singapore}

Before continuing with a detailed analysis of the growing number of Yap Ah Loy biographies, it is important to note critical changes underway at this time in the Chinese worlds within China and abroad. The Communist victory on the mainland, the KMT retreat to Taiwan, and the increasing pressures for national independence in Singapore and Malaya in the late 1940s and early 1950s dramatically changed the political situation of Chinese everywhere. Overseas Chinese, many of whom had never considered themselves permanent residents of Southeast Asia, were forced to rethink this position and ultimately to choose between returning to China or becoming citizens of the newly evolving Southeast Asian nation states. While mainland Chinese turned inward with their own massive economic, political, and social reform programmes, the Chinese in Malaya and Singapore became involved in attempts to establish new cultural as well as political identities for themselves in their new countries. The growing interest in Yap Ah Loy, now labelled the founding father of the Malayan capital of Kuala Lumpur, must be understood within the context of such social and political developments.

The first clear statement of the new importance placed on Yap Ah Loy's link with Kuala Lumpur appeared in an article published in Singapore in 1950 in the leisure magazine Xingqi liu (Saturday) entitled "Ye A Lai da zhoufu de gushi" (The Story of

${ }^{47}$ Link, Mandarin Ducks, p. 22.

${ }^{48}$ Zhang Liqian, "Ye Lai". See Note 23.

${ }^{49}$ Anon., "Ye Delai xiansheng yishi" [Anecdotes of Mr. Ye Delai] in Malaia huiqiao zonglan (Singapore: Dahuo chubanshe, 1949), pp. 59-61; Anon., "Ye Delai", in Pili Keshi gonghui kaimu jinian tekan (Ipoh, 1951), pp. 509-511.

${ }^{50}$ Anon., "Ye Delai chuan", in Nanyang nianjian, ed. You Shugun (Singapore: Nanyang baoshe youxiangongce, 1951), p. 96. 
Ye Ah Lai's Founding of the Capital). ${ }^{51}$ The key elements in the story-line, however, were not so much about the physical establishment and governance of Kuala Lumpur as the battles which surrounded the Selangor wars, with magical and religious factors given prominence, a trend which was relatively short lived. The story, while considerably more accurate in certain respects than those written on the Chinese mainland, still followed the basic form of the heroic leader of Chinese popular fiction.

Yap Ah Loy was described as being born under good omens: "upon hearing his cries when he came to earth, people said about him 'the dragon is capable of ascending to heaven, the snake can then descend to hell"'. ${ }^{2}$ However, due to poor training at home and contact with bad elements "he became involved in creating disturbances in the countryside the likes of which the gods detest and the spirits abhor, so that his parents also were not able to harbour him any longer, and it was best to tell him to leave the country". ${ }^{53}$ Arriving in Malacca he joined the secret society known as the Tiendi hui which sent him to Rawang where he met the soon-to-be-deified Kapitan Shin who made him one of his guards. Following his death, the former Kapitan revealed himself in a dream as Si Sen Ta, instructing Yap Ah Loy to protect his brothers when the barbarians began to create disturbances, as would soon happen. The rest of this account dealt largely with battles fought with both Malays and Chinese during the Selangor disturbances with considerable, although not total, accuracy.

The author of this piece, in describing the unruliness of Yap Ah Loy's behaviour during his youth, displayed a sensitivity to the dangers posed by those who sought power through strong-arm tactics. Mention of his association with secret societies by five authors in the 1950s and early 1960s similarly suggest some uneasiness with the underpinnings of his power. While this discomfort among Chinese-educated writers with some of the qualities of their historic hero did not always surface so directly, it is interesting to note that six Chinese authors during this period found it appropriate to cite the former British colonial officer Frank Swettenham's praise of Yap Ah Loy, in an effort it would seem to increase the man's respectability. ${ }^{54}$

The 1951 publication of an extensive English biography of Yap Ah Loy, researched and written largely by S.M. Middlebrook, a British colonial officer killed during the Japanese occupation of Singapore, significantly altered public knowledge of the famous Kapitan in Singapore and Malaya. One must assume that from 1951 on, Englisheducated Chinese and even some who were largely Chinese educated could have had access to this source. The Middlebrook biography did, in fact, become the major basis for Wang Zhiyuan's book-length Chinese biography published first in serial form in 1956 in the Singapore magazine Xingqi liu, and then in book form in 1958..$^{55}$

The differences between the English and Chinese versions of this biography are instructive, especially since entire chapters from the middle sections of Middlebrook's work were translated verbatim by Wang with no additional comment. What Wang did

\footnotetext{
${ }^{51}$ Lao Han, "Ye A Lai da zhoufu de gushi", Xingqi liu 24 (1950): 6.

${ }^{52}$ Lao Han, "Ye A Lai....", p. 6. Ruhlmann notes that in Chinese popular fiction the birth of founders (of dynasties, etc.) is typically accompanied by supernatural omens. Ruhlmann, "Traditional Heroes in Chinese Popular Fiction", p. 159.

${ }^{53}$ Lao Han, "Ye A Lai....", p. 6.

${ }^{54}$ Note, however, the changing attitude of Swettenham towards Yap in Chew, "Frank Swettenham and Yap Ah Loy".

${ }^{55}$ Wang Zhiyuan, "Ye Delai chuan", Xingqi liu 345/368 (1956). (Published in book form, Kuala Lumpur: Yihua chuban yinshua youxiangongce, 1958.)
} 
add however, were the (probably apocryphal) stories about Yap Ah Loy's childhood, where his chivalrous and heroic character first became evident. Again, as in other Chinese accounts, the message conveyed was that one was born with heroic traits which then manifested themselves in actions throughout one's life. Middlebrook, on the other hand, although clearly an admirer of Yap Ah Loy, located the man's greatness in his actions, which were as meticulously documented as the sources allowed.

Three new biographies of Yap Ah Loy appeared in 1954. The first, by Lu Baiye, was included in a general book about Malaya and focused on Yap Ah Loy's role in the building of Kuala Lumpur. ${ }^{56}$ While clearly drawing information from the Middlebrook account, $\mathrm{Lu}$ Baiye continued to dwell on what he referred to as Yap Ah Loy's generous and heroic qualities. The other two, published in the popular magazine Xingzhou zhoukan were both shorter in length and more wandering in their story-line. One focused on the relationship between Yap Ah Loy (described as chivalrous and a working man's leader) with the miraculous Si Shi Ye, ${ }^{57}$ while the other entitled "Kuala Lumpur's King Ye De Lai" labelled him as a legendary grassroots hero. ${ }^{58}$ This second account contained many of the details of the Middlebrook version presented in somewhat garbled form, with the emphasis, not surprisingly, on Yap Ah Loy's many contributions to the building of Kuala Lumpur. The significant factor in all of these accounts, however, was the continued emphasis on Yap Ah Loy's heroic qualities which attracted people to his side.

By the late 1950s, stories about Yap Ah Loy had taken on a much more uniform story-line. Tales about being a working man's hero or a leader of the labouring masses disappeared and there was a gradual shift from a continued interest in battle accounts in some of the late 1950s versions to increased attention to Yap Ah Loy's roles as an innovative businessman, a city administrator, and a philanthropist. ${ }^{59}$

During the 1960s, Chinese Malaysian accounts of Yap Ah Loy's life changed again in a more subtle but no less important way. While the contents of these versions continued to follow the now widely standardized Middlebrook story, their interpretations of Yap Ah Loy's success changed from the pre-ordained success of a charismatic leader to the earned respect of personal accomplishment based on hard work and determination. For example, Chen Yuxue, while titling his article, "Folk Hero Yap Ah Loy", described him as "not a mythical type of hero, but a very remarkable human being" who personally led his soldiers, and whose accomplishments were based not on luck but on his own personal determination and his ability to overcome difficulties. ${ }^{60}$ In Chen's eyes, Yap

${ }^{56} \mathrm{Lu}$ Baiye, "Jilengpo kaiji ren Ye A Lai" [Kuala Lumpur's founder: Ye A Lai] in Malai Sanji (Singapore: Xingzhou shijie shuju youxiangongce yinhang, 1954), pp. 39-49.

${ }^{57}$ Xiang $\mathrm{Zu}$, "Ye A Lai yu shiye miao" [Ye A Lai and the shiye temple], Xingzhou zhoukan 153 (1954): 5.

${ }^{58} \mathrm{Yu} \mathrm{Si}$, "Jilengpo wang Ye Delai" [The king of Kuala Lumpur: Ye Delai], Xingzhou zhoukan 150 (1954): 16-17.

${ }^{59}$ Anon., "Ye Delai", in Malaia tongshi: Malaia lianhebang huawen zhongxue keban disi zhi diwu xuenian shiyung (Kuala Lumpur: Malaia wenhua shiye youxiangongce yinhang, 1959), pp. 126-36; Chen Changhao, "Jilengpo huaren jiabidan Ye A Lai" [Kuala Lumpur's Chinese Kapitan Ye A Lai] in Malaia lishi mingren chuan (Kuala Lumpur: Wenhua gongyingshe, 1958), pp. 36-41; Zhang Jingwen, "Xuelanou jiabidan Ye Gong De Lai fenjan shilu" [Historical accounts of the struggles of Selangor's Kapitan Ye Delai] in Jilengpo xiansishiye gong chuangmiao shilu (Kuala Lumpur: Yingxing yinwuju, 1959).

${ }^{60}$ Chen Yuxue, "Minzu yingxiong Ye A Lai" [Hero of the people: Ye A Lai], Nanyang wenzhai 1, vol. 1 (1960): 55-56. 


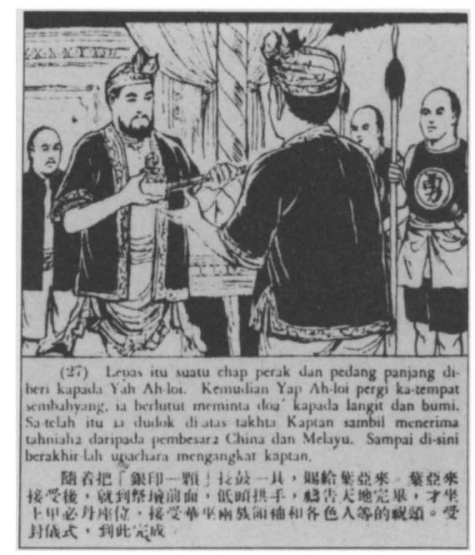

\section{Illustration 3}

Yap Ah Loy is appointed Kapitan of Kuala Lumpur. Anon., Kapitan Yap Ah Loi

(Singapore: The Commercial Press, 1962)

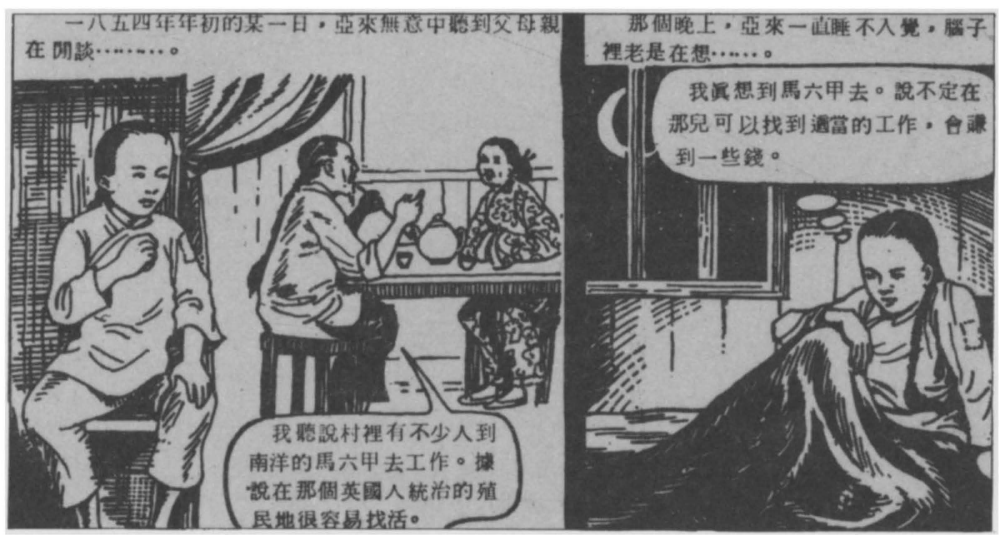

\section{Illustration 4}

The young Yap Ah Loy considers going to Malaya. Ma Zu, Jiabidan Ye A Lai Huachuan [Illustrated chronicle of Kapitan Ye $A$ Lai] (Kuala Lumpur: Fanma chuban youxiangongce, 1977) 
Ah Loy clearly earned his position as leader of Kuala Lumpur. In a similar manner, Feng Rulu (1961) called Yap Ah Loy a hero, and then proceeded to describe his life in careful detail, ascribing his success again and again to frugality, industry, and determination. ${ }^{61}$ Mei Jing (1961) attributed Yap Ah Loy's achievements to intelligence, courage, and loyalty, while Wu Xiabing (1962) paid credit to his interest in new things even as a young child, and his bravery, determination, and good governance which earned people's love and respect. ${ }^{62}$ This type of interpretation of personal success closely tracked English accounts published in books about Malayan pioneers at about this time. ${ }^{63}$

The twenty-year period from the end of the Second World War through 1965 was an era when the Chinese educated of Malaysia and Singapore worked most intensively to establish the concept of an officially recognized Chinese cultural presence in the area: a Chinese culture which was to be locally defined and which would continue to grow and develop with the support of local Chinese schools, a local Chinese literary community, and a local Chinese press. ${ }^{64}$ Within this milieu it is not surprising to find over twenty new articles and books about Yap Ah Loy produced during these years, as they argued for recognition of a Chinese place in Malaysian history, by crediting a Chinese with the founding of the nation's capital. Moreover, these stories must have reached a large audience, appearing as they did in a wide variety of publications ranging from academic books and journals to leisure magazines, clan association books, young people's books and even comic book versions (see illustrations 3 and 4).

After 1965, however, following the withdrawal of Singapore from Malaysia, the hopes of developing localized versions of Chinese culture based on Chinese education were greatly diminished, and with this the interest in supporting local Chinese publications. ${ }^{65}$ Thus, between 1965 and 1980 not only did the number of new Yap Ah Loy biographies decrease to six, but their venue of publication largely shifted from publicly circulated books and journals to privately produced and distributed clan

\footnotetext{
${ }^{61}$ Feng Rulu, "Ye A Lai de fengyun jijui" [Ye A Lai's gathering of heroes] in Malaia shihua (Hong Kong: Xianggang shanghui shuju chuban zongfahang, 1961), pp. 151-55.

${ }^{62}$ Mei Jing, ed., "Zhuming de huaren jiabidan Ye A Lai" [The famous Chinese Kapitan Ye A Lai] in Malai mingren chuan (Singapore: Shanghai shuju youxiangongce, 1961), pp. 59-83; Wu Xiabing, "Sanjian jilengpo de Ye A Lai" [Three times builder of Kuala Lumpur: Ye A Lai] in Malaia diangu (Singapore: Xinjiapo dongya wenhua shiye youxiangongce, 1962), pp. 153-59. See also Ma Zu, "Zhuming de huaren jiabidan Ye A Lai" [The famous Chinese Kapitan Ye A Lai]", Nanyang wenzhai 3, no. 1 (1962): 56-57 and Anon., Kapitan Yap Ah Loi (Singapore: The Commercial Press, 1962). This last is an illustrated children's book in Chinese and Malay. See illustration 3.

${ }^{63}$ Parkinson, Gullick and Hawkins, and Dally described Yap Ah Loy as moral, courageous, and determined. Attributing his success to clever capitalist schemes, they praised him for carrying out his civic duty. Ann and Cyril Parkinson, "Yap Ah Loy", in Heroes of Malaya (Singapore: Donald Moore Press, 1956), pp. 68-78; John Gullick and Gerald Hawkins, "Yap Ah Loy", in Malayan Pioneers (Singapore: Eastern Universities Press, 1958), pp. 22-28; Ranu Dally, Yap Ah Loy: Capitan China (Singapore: Donald Moore Press Ltd., 1969). On a rather different note, more sensationalist articles in English newspapers and news magazines highlighted the "brutal and backward" nature of early Kuala Lumpur under Yap Ah Loy's leadership, contrasting this with the civility and modern amenities brought by the British. H.T.S., "Yap Ah Loy, Founder of Kuala Lumpur”, Straits Times (24 December 1960); Donald Davies, "Yap Ah Loy, Capitan China", Malayan Times (20 May 1962); Gerald Delikhan, "Captain China: Forgotten Founder of a Capital", Alice Magazine (3 March 1962).

${ }^{64}$ Carstens, "Chinese Publications...."

${ }^{65}$ Ibid.
} 
association books. ${ }^{66}$ While Yap Ah Loy was still identified as Kuala Lumpur's founder in the school textbooks of this period, he attracted little additional public attention.

All of this changed in 1980, when the Malay Minister of Culture, Youth and Sports challenged Yap Ah Loy's founder's status, substituting instead the name of Raja Abdullah, a member of one of the Malay royal families who had helped sponsor the first large scale tin mining venture in the Kuala Lumpur area. In the debate which followed, accounts of Yap Ah Loy's life, based largely on the Middlebrook and Wang Zhiyuan versions, were printed repeatedly in Malaysian Chinese newspapers, as the Chinese fought a losing battle to defend the historical position of one of their own. This battle continues in some form even now, but accounts of this story must wait for another day. Let us, instead, review briefly some of the main issues of changing historical forms and changing political concepts displayed in the earlier narratives.

\section{Conclusion}

This paper has sought to document the manner in which repeated transformations of the Yap Ah Loy story reflected the changing political and social concerns of the times and places in which they were produced. In most cases, what passed for an historical account of one individual's life in reality communicated more about the author and his intended audience than about the individual himself. Thus, the earliest Chinese account, printed in the Selangor Journal, suggested political challenges to the residue of Yap Ah Loy's power in Kuala Lumpur in the 1890s, while the scarcity of further accounts in Malaya during the next fifty years implied a "lack of fit" between Yap Ah Loy's special qualities and those which were admired by the Malayan Chinese elite of that time. For early twentieth-century mainland Chinese intellectuals concerned about China's lack of power vis-à-vis the West, Yap Ah Loy represented both what individual Chinese could accomplish on their own, and what they might have become with the backing of a strong state. The stories of Wen Xiongfei and others, which made Yap Ah Loy into a working man's hero, suggested, among other things, the influence of populist ideologies current in China in the 1920s and 30s; and the stories of filial piety published in Taiwan reflected the continuing Confucian orientation of the ruling elite governing there in the late 1950s. In post-World War II Malaysia, the gradual growth in emphasis on Yap Ah Loy's contributions to the development of Kuala Lumpur paralleled the Chinese demands for recognition of their contributions to Malayan history.

\footnotetext{
${ }^{66}$ The two exceptions to this were Chien Kun, "Ye A Lai de yisheng" [The Life of Ye A Lai], Xingzhou re bao (28 February 1974): 1-5 and Ma Zu, Jiabidan Ye A Lai huachuan [Illustrated chronicle of Kapitan Ye A Lai] (Kuala Lumpur: Fanma chuban youxiangongce, 1977). Publications in Chinese association books included: Anon., "Ye Delai yishi" [Anecdotes of Ye Delai] in Senmilan huizhou huiguan bainian jinian tekan (Negri Sembilan, 1971), pp. 5-6; Anon., "Ye Delai", in Bingxiang yu keshigonghui sishi zhounian jinian kan (Penang, 1979); Li Yelin, "Ye A Lai chuanlu", [The chronicle of Ye A Lai] in Jilengpo guangdong yishan liushisan zhounian jinian tekan (Kuala Lumpur, 1978), pp. 15-16; Zeng Shuchen, "Ye A Lai da zhoufu de gushi" [The story of Ye A Lai's founding of the capital] in Bashen keshu gonghui zhounian jinian tekan (Kuala Lumpur, 1965), pp. 31-48. This last account was reprinted in Nanyang keshu zonghui sanshiwuliu zhounian kan (Singapore, 1967).
} 
Yet, the change in these stories was more than one of change in content and emphasis. There was an equally important alteration in the vision of leadership portrayed in the different versions. Over time, the qualities ascribed to Yap Ah Loy's leadership, which had been patterned after those of traditional Chinese heroes, were subtly altered to fit into a structure of secular history which could be communicated across cultural boundaries. His success, rather than being pre-ordained by some mythic order, was now credited to hard work and initiative which could be emulated and understood by anyone. That this alteration occurred in Chinese renditions of him suggests that Chinese Malaysian culture was also changing in the direction of a more secular understanding of itself, as Chinese Malaysians sought to adapt to the structures of an independent and multi-ethnic Malaysian society.

Finally, we need to remember that myths and other types of stories not only reflect the ideas and attitudes of groups of people at particular times, they also hold the power to shape perspectives and influence actions in very significant ways. Thus we can predict that historical biographies of men such as Yap Ah Loy, in whatever form they have occurred, did offer and will continue to offer lessons to Chinese Malaysians, as they proceed to recreate visions of history which inform meaningful responses to issues of current social and political concern. 


\section{GLOSSARY}

Chong Chong 张昌

gongren kuishou 工人魁首

Hui Fatt 丘发

Hui Zhou 惠州

Jinan Daxue 暨南大学

Jiaying Zhou 嘉应州

Kapitan Shin (Sheng Ming Li) 甲必丹盛(盛明利)

Liu Ngim Kong 刘王光

Si Sen Ta 四仙大

Tien di hui 天地会

tugu shijing zhi tu 屠活市井之徒

xiangren 乡人

Xinming zongbao 新民丵报

Xingqi liu 星期六

Xingzhou zhoukan 星洲周刊

xingzhuang 行状

Yap Ah Loy (Yap Tet Loy) 叶亚来(叶德来)

Yap Ah Shak 叶亚石

Yap Hon Chin 叶韩进

yi xiayi ganlien 以侠义干练 